\title{
Ateş nedeniyle Enfeksiyon Hastalıkları Kliniği'ne yatırılarak takip ve tedavi edilen hastaların retrospektif değerlendirilmesi
}

\author{
Retrospective evaluation of the febril patients hospitalized in the infectious diseases and \\ clinical microbiology department
}

\author{
Işıl Deniz Alıravcı, Esragül Akıncı, Sevil Alkan Çeviker
}

\section{Özet}

Amaç: Bu çalışmada ateş nedeniyle servisimize yatırılan hastalara ait verilerin değerlendirilmesi, ateş nedenlerinin irdelenmesi ve güncel durumun tekrar gözden geçirilmesi amaçlandı.

Gereç ve yöntem: Ocak 2011-Mayıs 2013 tarihleri arasında ateş şikayetiyle Enfeksiyon Hastalıkları ve Klinik Mikrobiyoloji Kliniği'mize yatırılarak izlenmiş olan 230 hasta retrospektif olarak incelendi.

Bulgular: Çalışmaya alınan 226 hastanın 208'inde ateş enfeksiyon kaynaklı, 18'inde ise enfeksiyon dışı nedenlere bağlı idi. Pnömoni, idrar yolu enfeksiyonu, Kırım Kongo Kanamalı Ateşi, selülit ve solunum yolu viral enfeksiyonları sırasıyla en sık saptanan enfeksiyonlardı. Nedeni bilinmeyen ateş (NBA) kriterlerine uyan 19 hasta mevcuttu. NBA olgularının \%53'ü enfeksiyon, $\% 21$ 'i inflamatuvar hastalık, $\% 10,5$ 'i malignite, $\% 10,5$ 'i etiyolojisi saptanamayan hastalık, \%5,3'ü diğer hastalıklar olarak gruplandırıldı. Başvuru öncesi hastaların \%65'i diğer sağlık kuruluşlarına başvurmuş, \%43'ü öncesinde antibiyotik kullanmıştı.

Sonuç: Bu çalışmada, hastaların büyük bir kısmında ateşin enfeksiyon kaynaklı olduğu, NBA grubunun ise küçük bir oranı oluşturduğu görülmektedir. Ateşe neden olan enfeksiyonlar arasında pnömoni ve üriner enfeksiyonların halen önemini koruduğu ve ateşli hasta grubunda etiyoloji belli olmadan antibiyotik kullanımının çok yaygın olduğu anlaşılmaktadır.

Anahtar kelimeler: Ateş, nedeni bilinmeyen ateş, enfeksiyon.

Alıravcı ID, Akıncı E, Alkan Çeviker S. Ateş nedeniyle Enfeksiyon Hastalıkları Kliniği'ne yatırılarak takip ve tedavi edilen hastaların retrospektif değerlendirilmesi. Pam Tıp Derg 2020;13:276-283.

\begin{abstract}
Purpose: The aim of this study was to evaluate the data of patients hospitalized for fever, to investigate the causes of fever and to review the current situation.

Materials and methods: Between January 2011 and May 2013, 230 patients who were admitted to our Infectious Diseases and Clinical Microbiology Department with fever were retrospectively evaluated.

Results: Of the 226 patients included in thestudy, fever was due to infection origin in 208 patients and noninfectious causes in 18 patients. Pneumonia, urinary tract infection, Crimean-Congo Hemorrhagic Fever, cellulitis and respiratory viral infections were the most common infections respectively. There were 19 patients with fever unknown origin (FUO) criteria. $53 \%$ of FUO cases were classified as infection, $21 \%$ inflammatory disease, $10.5 \%$ malignancy, $10.5 \%$ undetectable disease, $5.3 \%$ other diseases. $65 \%$ of the patients had applied to the health institutions before the admission and $43 \%$ had used various antibiotics.

Conclusion: In this study, it was seen that fever was the origin of infection in the majority of the patients and the FUO group constituted a small proportion. It is understood that pneumonia and urinary infections are still important among the infections causing fever and antibiotic use is very common in the febrile patients without specific etiology.
\end{abstract}

Key words: Fever, fever of unknown origin, infection.

Alıravcı ID, Akıncı E, Alkan Çeviker S. Retrospective evaluation of the febril patients hospitalized in the Infectious Diseases And Clinical Microbiology Department. Pam Med J 2020;13:276-283.

Işı Deniz Alıravcı, Uzm. Dr. Manavgat Devlet Hastanesi, Antalya, Türkiye, e-posta: dr_isildeniz@hotmail.com, (orcid.org/0000-0002-47401579) (Sorumlu Yazar)

Esragül Akıncı, Prof. Dr. Ankara Numune Eğitim ve Araştırma Hastanesi, Ankara, Türkiye, e-posta: esragulakinci@gmail.com, (orcid.org/ 00000003-3412-8929)

Sevil Alkan Çeviker, Uzm. Dr. Kütahya Sağıık Bilimleri Üniversitesi, Evliya Çelebi Eğitim Araştırma Hastanesi, Enfeksiyon Hastalıkları ve Klinik Mikrobiyoloji Bölümü, Kütahya, Türkiye, e-posta: s-ewil@hotmail.com, (orcid.org/0000-0003-1944-2477) 


\section{Giriş}

Vücut sıcaklığının normal günlük değişkenliğinin üzerine çıkacak şekilde yükselmesi ateş olarak tanımlanır [1]. Enfeksiyon hastalıklarının en sık karşılaşılan bulgularından biri olan ateş; tümörler, kollajen vasküler hastalıklar ve ilaçlar gibi enfeksiyon dışı nedenlere de bağlı olabilir [2, 3]. Ateş nedeni ile kliniklere başvuran hastaların çoğunluğuna tanı konulmakla birlikte, bir bölümünde yapılan inceleme ve araştırmalara rağmen ateş nedeni uzun süre saptanamamaktadır. Bu tablo ilk olarak Petersdorf ve Beeson tarafından 1961 yılında tanı konulmakta güçlük çekilen ateşlere yaklaşım kolaylığı getirmek amacıyla nedeni bilinmeyen ateş (NBA) olarak tanımlanmıştır [4]. Bugün de geçerliliğini koruyan bu tanıma göre üç haftadan uzun süren, $38,3^{\circ} \mathrm{C}$ 'nin üzerinde seyreden ve bir haftalık hastanede yapılan incelemeler sonucunda nedeni açıklanamayan ateş olarak tanımlanmıştır. 1991 yılında Durack ve Street klasik NBA'nın yanı sıra nozokomiyal NBA, nötropenik NBA ve insan immün yetmezlik virüsü (HIV) varlığında NBA'yı tanımlamıştır [5, $6]$.

$\mathrm{Bu}$ çalışmada ateş nedeniyle servisimize yatırılan hastalara ait verilerin değerlendirilmesi, ateş nedenlerinin irdelenmesi ve güncel durumun tekrar gözden geçirilmesi amaçlanmıştır. Ayrıca nedeni bilinmeyen ateş nedeniyle yatırılan hastalar değerlendirilerek ateşe neden olan hastalıklar ortaya konulmuştur.

\section{Gereç ve yöntem}

Çalışma üçüncü basamak tedavi hizmeti veren 1100 yataklı Ankara Numune Eğitim ve Araştırma Hastanesi Enfeksiyon Hastalıkları ve Klinik Mikrobiyoloji Kliniği'nde Ocak 2011-Mayıs 2013 tarihleri arasında yapıldı. Ateş nedeniyle $\left(>37,3^{\circ} \mathrm{C}\right.$, aksiller) kliniğe yatırılarak izlenen 230 erişkin hasta kayıtları retrospektif olarak incelendi. Ateş şikayeti ile kliniğe yatırılan fakat takibinde ateşi olmayan olgular, akkiz immün yetmezlik tanısı alanlar, nötropenik ateş tanımına giren hastalar (nötrofil $<500$ / $\mathrm{mm}^{3}$ ), nozokomiyal enfeksiyonu olanlar, diğer kliniklerden veya dış merkezlerden nakil alınan hastalar çalışma dışında bırakıldı. Bu hastalar üzerinde iki farklı değerlendirme yapıldı. İlk değerlendirmede enfeksiyon orjinli ateşi olan olgular ile, enfeksiyon dışı nedenlere bağlı ateşi olan olgular karşılaştıııldı. İkinci değerlendirmede ise nedeni bilinmeyen ateş (NBA) tanımına giren olgular irdelendi.

Çalışma verileri bilgisayara kaydedilerek, SPSS (Statistical Packagefor Social Sciences) Windows 19.0 programı kullanılarak değerlendirildi. Tanımlayıcı istatistiksel metodların (minimum-maksimum) yanı sıra, verilerin karşılaştırılmasında çapraz tablolar, verilerin karşılaştırılmasında Kikare, Kruskal Wallis ve Mann Whitney $U$ testleri kullanıldı. Sonuçlar 95'lik güven aralığında, anlamlılık $p<0,05$ düzeyinde değerlendirildi.

Çalışmanın yapılabilmesi için Ankara Numune Eğitim ve Araştırma Hastanesi'nden yerel etik kurul onayı alındı.

\section{Bulgular}

Ocak 2011-Mayıs 2013 tarihleri arasında kriterlere uyan 230 hasta çalışmaya alındı. Bu hastaların 19'u NBA nedeni ile yatırıldı. Tanısı konulan 226 hastanın 208'inde ateş enfeksiyon orjinli, 18'inde ise enfeksiyon dışı nedenlere bağlı idi. Hastaların 124'ü (\%54) erkek, 106'sı (\%46) kadın, yaş ortalaması 53 \pm 21 (17-94) idi. Eşlik eden kronik hastalıklar 142 (\%62) hastada tespit edildi.

Yatışta alınan öykülerine göre 80 hasta (\%35) kliniğimize yatırılmadan önce herhangi bir sağlık kurumuna başvurmamış, 15'i (\%6) I. basamak sağlık kurumlarında, 50'si (\%22) II. basamak sağlık kurumlarında, 85 'i (\%37) III. basamak sağlık kurumlarında değerlendirilmişti. Başvuru öncesi hastaların \%43'ü çeşitli antibiyotikler kullanmıştı. Hastaların çoğunun acil servisten yatışı yapılmış olup (Tablo 1), NBA grubundaki olgularının ise tamamı dış merkezlerden yönlendirilmiş; 4'ü $(\% 21,1)$ II. basamak, 15’i $(\% 78,9)$ III. basamak sağlık kuruluşlarından hastanemize gönderilmiş, $8(\% 42)$ hasta ise son 3 ay içinde çeşitli hastanelerde yatırılarak araştırıımıştı. NBA hastalarının antibiyotik kullanma oranı \%84 gibi yüksek bir oranda idi. Enfeksiyon orjinli ateş ve enfeksiyon dışı ateş grubundaki olgular medikal öyküleri açısından kıyaslandığında, enfeksiyon dışı ateş grubundakilerin başvuru öncesi antibiyotik kullanım oranları istatistiksel olarak anlamlı düzeyde yüksek bulundu $(p<0,05)$ (Tablo 2 ).

Tüm hastaların yatış esnasındaki ortalama ateş değeri $37,9 \pm 0,8^{\circ} \mathrm{C}$ (maksimum $40,1^{\circ} \mathrm{C}$ ), hastanedeki ortalama ateş süresi 1-15 gün, 
ortalama yatış süresi 1-45 gün idi. NBA grubundaki hastalarının hastaneye yatış sırasındaki ortalama ateş değeri $37,7 \pm 1,1^{\circ} \mathrm{C}$ (maksimum $39,0^{\circ} \mathrm{C}$ ), hastanedeki ortalama ateş süresi $7 \pm 4(1-15)$ gün, başvuru öncesi ortalama ateşli gün sayısı $31 \pm 24$ gün (20$90)$, ortalama yatış süresi 16+10 (4-45) gün olarak bulundu. Olguların 5'inde $(\% 26,3)$ ateş süresi 60 günden uzun idi. Bu olguların üçünde enfeksiyon (ikisinde enfektif endokardit, birinde apse), birinde kollajen vasküler hastalık (Behçet hastalığı) tespit edildi. Bir olguya ise tanı konulamadı. Başvuru öncesi ateşin ortalama süresi enfeksiyon dışı ateş grubunda, enfeksiyon orjinli ateş grubuna göre daha yüksek idi $(p>0,05)$. Yatıştaki ortalama ateş değeri ise enfeksiyon orjinli ateş grubundaki hastalarda istatistiksel olarak anlamlı derecede yüksekti $(p<0,05)$. Hastanedeki ortalama yatış süresi ve saptanan en yüksek ateş değeri her iki grupta benzer idi $(p>0,05)$.

Hastalarda en sık şikayetleri halsizlik (\%76), bulantı (\%43) ve öksürük (\%40); en sık saptanan fizik muayene bulguları akciğer seslerinde değişiklik (\%31), bilinç değişikliği (\%18) ve kooperasyon kısıtlılığı idi.

Laboratuvar değerleri incelendiğinde enfeksiyon dışı ateş grubunda ortalama trombosit sayısı istatistiksel olarak anlamlı düzeyde yüksekti $(p<0,05)$ (Tablo 3$)$.

Tüm hastaların 39'una (\%17) tanısal amaçlı invazif girişim uygulandı. Tanısal amaçlı yapılan bazı invazif girişimlerin (biyopsi, endoskopi, kolonoskopi vb) ve bazı görüntüleme yöntemlerinin (Ekokardiyografi, tomografi vb.) enfeksiyon orjinli ateş grubunda daha yüksek oranda olduğu tespit edildi $(p<0,05)$. NBA grubundaki hastaların ise 15 'ine (\%79) tanısal amaçlı invaziv girişim uygulandı. İki $(\% 10,5)$ olguya perkütan apse aspirasyonu, 7 (\%36,8) olguya biyopsi, $6(\% 31,5)$ olguya endoskopi/ kolonoskopi, bir $(\% 5,3)$ olguya torasentez ve bir $(\% 5,3)$ olguya da endoskopik retrograd kolanjiopankreotografi yapıldı. Görüntüleme yöntemleri arasında en fazla posterior anterior (PA) AC grafisi ve ultrasonografi; serolojik testler arasında ise Rose-Bengal, ELISA ve Brucella aglütinasyon testleri istendiği saptandı. Hastalardan alınan kültür sonuçları değerlendirildiğinde alınan 205 kan kültüründen 14 tanesinde üreme olduğu, bir hastanın kanında üreyen Staphylococcus hominis'in kontaminasyon olarak değerlendirildiği görüldü. Üç enfektif endokardit hastasında üreyen etkenler Staphylococcus epidermidis ve Viridans grubu streptokoklar idi. NBA grubundaki hastalardan ikisine kan kültürü sonucu ile Salmonella bakteriyemisi tanısı konuldu. Alınan 154 idrar kültürünün 48'inde, 34 gayta kültürünün birinde, 14 yara kültürünün 9'unda, 13 balgam kültürünün beşinde ve 8 beyin omurilik sıvısı (BOS) kültürünün birinde üreme saptandı. Bir NBA hastasının BOS kültüründe Brucella spp. üredi. Üreyen mikroorganizmaların sayılarına bakıldığında, mevcut üremelerin çoğunluğunu Escherichia coli suşlarının oluşturduğu tespit edildi.

Çalışma grubunda yer alan 230 olgunun 226'sına fizik muayene, laboratuvar tetkikleri ve görüntüleme yöntemleri ışığında tanı konuldu. Tanı konulamayan dört hastanın ateşleri kendiliğinden düştü. Tanısı konulan 226 hastanın çoğunluğunu enfeksiyon hastalıklarının oluşturduğu saptandı. Enfeksiyon orjinli ateş grubunda 208, enfeksiyon dışı ateş grubunda 18 hasta yer aldı (Tablo 4). Pnömoni, idrar yolu enfeksiyonu, KKKA, selülit ve solunum yolu viral enfeksiyonları sırasıyla en sık saptanan enfeksiyonlardı. NBA olgularının \%53'ü enfeksiyon, \%21'i inflamatuvar hastalık, \%10,5'i malignite, \%10,5’i etyolojisi saptanamayan hastalık, \%5,3'ü diğer hastalıklar olarak gruplandırıldı. NBA hastalarında en sık saptanan enfeksiyon enfektif endokardit idi (Tablo 5). Non-enfekte hasta grubunda yer alan hastaların tanıları; malignite, Behçet hastalığı, pulmoner emboli, Crohn hastalığı aktivasyonu, erişkin Still hastalığı, Adisson krizi, kronik obstrüktif akciğer hastalığı (KOAH) alevlenme, serebrovasküler hastalık, Çölyak hastalığı, toksik olmayan multinodüler guatr, Ailevi Akdeniz Ateşi (Familial Mediterranean Fever) (FMF) alevlenmesi, megaloblastik anemi, Henoch-Schönlein purpurası, akut kolesistit ve vaskülit idi.

Tüm hastaların 188'inde antibiyotik tedavisi ile, 42'sinde semptomatik tedavi ile klinik iyileşme sağlandı. Seftriakson (\%31,4), meropenem/ imipenem (\%15,4), moksifloksasin (\%15,4), ampisilin-sulbaktam $(\% 13,3)$ ve klaritromisin $(\% 12,2)$ en sık kullanılan ilk beş antibiyotik arasında yer aldı. Hastaların \%90'ı (208 hasta) tedavi sonrası taburcu edildi; 11 hasta hastane içindeki ilgili kliniklere nakil verildi, 11 hasta ise kaybedildi. 
Tablo 1. Enfeksiyon kaynaklı, enfeksiyon dışı ateş ve nedeni bilinmeyen ateş (NBA) grubundaki hastaların medikal öykülerinin değerlendirilmesi.

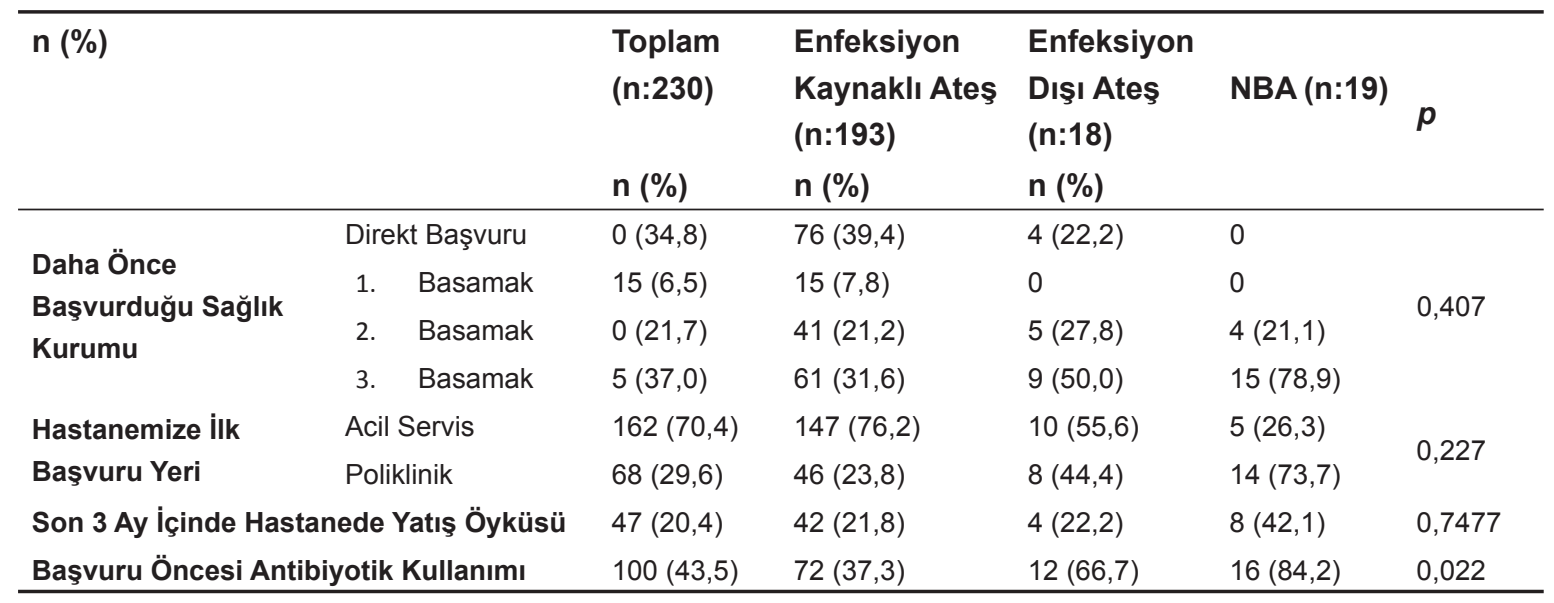

*NBA: Nedeni bilinmeyen ateş.

Tablo 2. Hastalardaki ateş süresinin değerlendirilmesi.

\begin{tabular}{|c|c|c|c|c|c|}
\hline & \multicolumn{2}{|c|}{ Enfekte $(n=208)$} & \multicolumn{3}{|c|}{ Non-enfekte $(n=18)$} \\
\hline & $\begin{array}{l}\text { Ortalama } \\
\text { Değer }\end{array}$ & $\begin{array}{l}\text { Standart } \\
\text { Sapma }\end{array}$ & $\begin{array}{l}\text { Ortalama } \\
\text { Değer }\end{array}$ & $\begin{array}{l}\text { Standart } \\
\text { Sapma }\end{array}$ & $p$ \\
\hline Başvuru öncesi ateş süresi (gün) & 6 & 10 & 13,5 & 17 & 0,064 \\
\hline Yatış esnasında ortalama ateş $\left({ }^{\circ} \mathrm{C}\right)$ & 37,9 & 0,8 & 37,4 & 0,9 & 0,023 \\
\hline En yüksek ateş $\left({ }^{\circ} \mathrm{C}\right)$ & 38,4 & 0,7 & 38,4 & 1,0 & 0,730 \\
\hline Hastanedeki ateş süresi (gün) & 3 & 2 & 3,5 & 4 & 0,918 \\
\hline Hastanedeki yatış süresi (gün) & 7,4 & 6 & 6,6 & 4 & 0,791 \\
\hline
\end{tabular}

Tablo 3. Olguların labaratuvar bulgularının değerlendirilmesi.

\begin{tabular}{|c|c|c|c|c|c|}
\hline & $\begin{array}{l}\text { Toplam Ortanca } \\
\text { (min-max) }\end{array}$ & $\begin{array}{l}\text { Non enfeksiyöz } \\
\text { Ortanca (min-max) }\end{array}$ & $\begin{array}{l}\text { Enfeksiyöz Ateş } \\
\text { Ortanca (min-max) }\end{array}$ & $\begin{array}{l}\text { NBA Ortanca } \\
\text { (min-max) }\end{array}$ & $p$ \\
\hline Üre (mg/dL) & $31(5-161)$ & $28(5-124)$ & $32(8-161)$ & $30(13-123)$ & 0,199 \\
\hline $\begin{array}{l}\text { Kreatinin } \\
\text { (mg/dL) }\end{array}$ & $0,8(0,1-10,8)$ & $0,8(0,2-2)$ & $0,8(0,1-10,8)$ & $0,8(0,5-6,2)$ & 0,881 \\
\hline AST (U/L) & $25(6-1663)$ & $26(12-221)$ & $25(6-1663)$ & $22(9-181)$ & 0,942 \\
\hline $\operatorname{ALT}(\mathrm{U} / \mathrm{L})$ & $19(1-1861)$ & $27(9-327)$ & $18(1-1861)$ & $19(8-202)$ & 0,256 \\
\hline$A L P(U / L)$ & $72,5(23-423)$ & $67(36-394)$ & $72,5(23-423)$ & $100(27-303)$ & 0,221 \\
\hline GGT(U/L) & $29,5(5-3904)$ & $32(6-298)$ & $27(5-3904)$ & $46(16-206)$ & 0,053 \\
\hline T BíL (mg/dl) & $0,5(0,1-15,5)$ & $0,6(0,1-15,5)$ & $0,6(0,1-7,7)$ & $0,5(0,1-1,8)$ & 0,168 \\
\hline $\operatorname{LDH}(\mathrm{U} / \mathrm{L})$ & 341 (79-2655) & $394(127-1990)$ & $330(92-2655)$ & $341(79-1020)$ & 0,564 \\
\hline ESR (mm/saat) & $38(0-150)$ & $36(4-150)$ & $35,5(0-140)$ & $67(9-120)$ & 0,019 \\
\hline CRP (U/I) & $55(0,5-20000)$ & $92(0,5-347)$ & $49,5(0,5-20000)$ & $85(1,4-296)$ & 0,197 \\
\hline $\begin{array}{l}\mathrm{WBC}(/ \mathrm{mm} 3) \\
\text { (ort) }\end{array}$ & $10(1-38,3)$ & $8,7(1,3-24,5)$ & $10,1(1-33)$ & $11,7(4,8-38,3)$ & 0,162 \\
\hline $\begin{array}{l}\text { Not }(/ \mathrm{mm} 3) \\
\text { (ort) }\end{array}$ & $7700(100-940)$ & $7200(100-910)$ & $7800(250-940)$ & $7400(260-940)$ & 0,286 \\
\hline $\mathrm{HGB}(\mathrm{g} / \mathrm{dL})$ & 12,6 & 12,3 & 12,7 & 11,3 & 0,086 \\
\hline $\begin{array}{l}\mathrm{PLT}(/ \mathrm{mm} 3 \text { ) } \\
\text { (ort) }\end{array}$ & 206 & 195 & 203,5 & 292 & $<0,001$ \\
\hline
\end{tabular}

*ALT: Alanin Amino transferaz, AST: Aspartat amino transferaz, CRP: C- reaktif protein, GGT: Gama-glutamil transferaz, ESR: Eritrosit Sedimentasyon Hızı, HGB: Hemoglobin, LDH: Laktat dehidrogenaz, min: minimum, max: maximum, NBA: nedeni bilinmeyen ateş, PLT:Platelet, NÖT:Nötrofil, WBC: White blood cell (beyaz kan hücresi). 
Tablo 4. Hastalara uygulanan tanısal yöntemlerin değerlendirilmesi.

\begin{tabular}{lllll}
\hline & & Enfekte $\mathbf{( n = 2 0 8 )}$ & Non-enfekte $\mathbf{( n = 1 8 )}$ & $\boldsymbol{p}$ \\
\hline İnvaziv girişim & Apse aspirasyonu & 5 & 0 & 0,506 \\
& Lomber ponksiyon & 8 & 0 & 0,397 \\
& Biyopsi & 10 & 4 & 0,003 \\
& Endokopi/kolonoskopi & 6 & 4 & 0,000 \\
& Torasentez/plevral drenaj & 4 & 1 & 0,315 \\
Nefrostomi değişimi & 1 & 0 & 0,768 \\
Direkt grafi & Perkütan kolesistostomi & 1 & 0 & 0,768 \\
İleri görüntüleme & PAAC grafisi & 208 & 18 & 0,210 \\
yöntemleri & Waters sinüs grafisi & 7 & 0 & 0,429 \\
& USG & 118 & 13 & 0,201 \\
& BT & 37 & 6 & 0,107 \\
& Doppler USG & 10 & 2 & 0,253 \\
& MRI & 16 & 2 & 0,837 \\
& EKO & 26 & 8 & 0,000 \\
& BT anjiyografi & 6 & 0 & 0,465 \\
MR venografi & 2 & 1 & 0,102 \\
& EEG & 0 & 0,001 \\
\hline
\end{tabular}

Tablo 5. Nedeni bilinmeyen ateş grubundaki hastaların tanıları.

\begin{tabular}{lll}
\hline & Sayı & $\%$ \\
\hline 1-ENFEKSiYONLAR & 10 & 53 \\
Enfektif endokardit & 3 & 15,7 \\
Apse & 2 & 10,5 \\
Nörobruselloz & 1 & 5,3 \\
Fasciola hepatica & 1 & 5,3 \\
Salmonella bakteriyemisi & 2 & 10,5 \\
Akut sinüzit & 1 & 5,3 \\
2-Kollajen-vasküler hastalıklar & 4 & 21 \\
Behçet hastalığı & 2 & 10,5 \\
Erişkin Still hastalığı & 1 & 5,3 \\
Lökositoklastik vaskülit & 1 & 5,3 \\
3-Malignite & 2 & 10,5 \\
Rektum & 1 & 5,3 \\
Mide & 1 & 5,3 \\
4- Diğer & 1 & 5,3 \\
Toksik olmayan multinoduler guatr & 1 & 5,3 \\
5-Tanı Konulamayan & 2 & 10,5 \\
\hline
\end{tabular}




\section{Tartışma}

$\mathrm{Bu}$ çalışmada, enfeksiyon hastalıkları kliniğine ateş nedeni ile başvuran hastaların büyük çoğunluğunun (\%90) ateş nedeninin enfeksiyon orjinli olduğu, NBA grubunun \%8 gibi küçük bir oranı teşkil ettiği görülmüştür. Pnömoni, idrar yolu enfeksiyonu, KKKA, selülit ve solunum yolu viral enfeksiyonları sırasıyla en sık saptanan enfeksiyonlar idi.

Çalışmada ateş nedeniyle hastaların çoğunlukla 3 . basamak sağlık kuruluşlarına başvurdukları ve genellikle de acil servisten giriş yaptıkları görülmüştür. Bu sonuç, ateşin halk arasında acil ve ciddi bir durum olarak algılandığı ve tam teşekküllü hastanelere başvurma intiyacı oluşturduğu izlenimini vermektedir. Acil serviste randevu sistemi olmaması ve sıra beklemeden muayene olunması, hastaların mesai saatlerinde hastaneye yetişememesi gibi nedenlerin de bu sonucu etkileyen faktörler olduğu düşünülmektedir. NBA hasta grubundaki hastalarda ise acil servisten başvuru oranı daha düşüktür. Bu hastalarda ateşin daha uzun süredir devam ediyor olması ve önceden başka hastanelere başvuru yapılmış olması bu kişilerde acil bir durum olmadığı kanaatini oluşturmuş olabilir. Karan ve ark. [7] çalışmasında NBA olguları üzerinde yaptıkları çalışmada hastaların \%35'inin 3. basamaktan, \%23'ünün 2. basamaktan sevk edildiği belirtilmiştir.

Diğer taraftan, ateşli hastalarda başvuru öncesi antibiyotik kullanım oranının çok yüksek olduğu, NBA olgularında bu oranın daha da arttığı dikkati çekmektedir. Başvuru öncesi antibiyotik kullanımı NBA olgularında $\% 84,2$ gibi yüksek bir oranda tespit edilirken tüm hastalarda bu oran \%43,5 idi. Olguların çoğunda ilk basamak tetkiklerle tanıya gidilmesine rağmen NBA grubunda daha fazla ek tetkike intiyaç duyulmuştur. Demirve ark. [8] çalışmasında NBA hastalarında yaptıkları çalışmada hastaların $\% 40$ 'ında son altı ay içinde antibiyotik kullanım öyküsü olduğu görülmektedir. Tetkik olanağı yetersiz olan veya hekimin yetersiz kaldığı sağıı merkezlerinde ateş odağı saptanmasa dahi antibiyotik kullanımı sık rastlanan bir durumdur. Ateşli hastaya antibiyotik başlamış olmanın psikolojik olarak rahatlatıcı bir etkisi olduğu bilinen bir gerçektir. Özellikle NBA grubunda antibiyotik kullanım sıkığının \%84,2 olması; enfeksiyon dışı ateş grubunda, enfeksiyon orjinli ateş grubuna oranla anlamlı olarak daha fazla antibiyotik kullanmış olması bu düşünceyi desteklemektedir.

Köse ve ark. [1] çalışmasında yüksek ateş şikayetiyle başvuran hastalarda yaptıkları çalışmada olguların ortalama ateş yüksekliğinin 8 gün olduğunu bildirmiştir. NBA olgularında Çağatay ve ark. [9] çalışmasında ortalama ateş süresini 43 gün, Alpat ve ark. [9] 24 gün, Zorlu ve ark. [10] 20 gün olarak saptamışlardır. Çalışmamızda ise, tüm grupta başvuru öncesi ortalama ateş süresi 7 gün, NBA grubunda ortalama 31 gün olarak tespit edildi. Hastaların daha önce başka merkezlere başvurusu ve tetkik edilmesinin bu sonuçta etkili olduğu; NBA hastalarının komplike olması nedeniyle başvurduğu her basamakta daha uzun süre tetkik ve tedavi edilmesinin süreyi daha da uzattığı düşünülmektedir. Köse ve ark. [1] çalışmasında yüksek ateş şikayetiyle başvuran hastalarda ortalama yatış süresini 12 gün olarak tespit etmiştir. Zorlu ve ark. [6] NBA grubunda yaptıkları çalışmada hastaları ortalama olarak 20 gün, Alpat ve ark. [10] ise 11 gün kadar yatırarak tedavi etmişlerdir. Bu çalışmada ise, bulunan sonuçlar benzer olup hastanede ortalama yatış günü ateşli hastaların tümünde 7 gün, NBA grubunda 16 gün olarak saptandı.

Nedeni bilinmeyen ateş hastalarında, fizik muayenenin tamamlanmasından sonra ateşe yönelik odak bulunamaması sık rastlanan bir durum olup, bu hastalarda günde 2-4 kez ayrıntılı muayene yapılması önerilmektedir [11]. Bu çalışmada en sık fizik muayene bulgusunun akciğer dinleme bulgusu olduğu, bunu bilinç değişikliği ve kooperasyon kısıtlııı̆ının takip ettiği saptanmıştır. En sık enfeksiyon grubunun pnömoni olması, akciğerlerdeki dinleme bulgusunun sıklığını açıklamaktadır. Yüksek ateşin kendisi özellikle yaşlı ve komorbid nörolojik hastalığı (Alzheimer, epilepsi vb.) olan hastalarda bilinç değişikliğine yol açmaktadır. Ayrıca bilinç bulanıklığı ve kooperasyon kısıtlıı̆ğ santral sinir sistemi (SSS) enfeksiyonlarının önemli semptomları arasında yer almaktadır. Çalışmada diğer önemli bir fizik muayene bulgusu olarak batında ağrılı hassasiyet, kostovertebral açı hassasiyeti ve suprapubik hassasiyet saptandı. Bu bulgular da ikinci en sık tanı olan idrar yolu enfeksiyonu varlığı ile açıklanabilir. NBA grubundaki fizik muayene bulguları incelendiğinde, benzer şekilde akciğer dinleme bulgularının daha sık saptandığı 
görülmektedir. Yaşlı hastalarda toplum kaynaklı enfeksiyonların değerlendirildiği bir çalışmada, idrar yolu enfeksiyonu, gastroenterit, pnömoni ve yumuşak doku enfeksiyonu en sık saptanan enfeksiyonlar olarak belirtilmiştir [12]. Köse ve ark. [1] ateşli hastalarda yaptıkları çalışmada, hastaların en sık akut menenjit ile takip edildikleri, bunu takiben idrar yolu enfeksiyonu ve pnömoninin yer aldığı görülmektedir. Goto ve ark. [13] çalışmasında ateşli hastalarda en sık pnömoni ve bronşit, bunu takiben pyelonefrit tespit edilmiştir. Bu çalışmada en sık pnömoni, ikinci sıklıkla pyelonefrit, üçüncü sıklıkta ise KKKA yer almıştır. Bunun en önemli sebebi hasta popülasyonumuzun yaşlı, bakımevlerinde kalan hasta grubu olması ve/veya predispozan faktörleri içermesidir. Ayrıca yakın geçmişte ülkemizde hızla yayılan KKKA enfeksiyonu için hastanemizin önemli bir merkez olması sebebiyle hastalığın görüldüğü bahar ve yaz aylarında KKKA hasta sayısında artış olmaktadır. Goto ve ark. [13] ateşli hastalar üzerinde yaptığı retrospektif çalışmada olguların \%12,8'si, Çağatay ve ark. [9] ise çalışmasında \%3,4'ü NBA olarak değerlendirilmiştir. Bu çalışmada yer alan tüm hastaların \%8,3'ünün NBA grubu olduğu saptanmıştır. NBA hastalarının \%53'ü enfeksiyonlar, \%21'i inflamatuvar hastalıklar, $\% 10,5$ 'i maligniteler, \%10,5'i etyolojisi saptanamayan hastalıklar ve \%5,3'ü diğer hastalıklar olarak tespit edilmiştir. Saka ve ark. [14] çalışmasında olguların \%42'si enfeksiyonlar, \%30'u inflamatuvar hastalıklar, \%18'i maligniteler, \%10'u etyolojisi saptanamayan grup olarak belirtilmiştir. Küçükardalı ve ark. [15] ise çalışmasında vakaların \%60'ı enfeksiyonlar, \%7'si inflamatuvar hastalıklar, \%11'i maligniteler, \%20'si etyoloji saptanamayan, \%2'si diğer olarak tanımlanmıştır. Alpat ve ark. [10] çalışmasında, vakaları \%32 enfeksiyonlar, $\% 19$ inflamatuvar hastalıklar, \%9 maligniteler, \%25 etyolojisi saptanamayan, \%15 de diğer grup olarak sınıflamıştır. Geçmiş dönemde yapılan çalışmalarda ülkemizde NBA grubunda en sık enfeksiyon tüberküloz iken günümüzde tüberkülozun azalması ve göğüs hastalıkları kliniğine yönlendirilmesi sebebiyle bu çalışmada tüberküloz enfeksiyonuna hiç rastlanmamıştır [10]. Zorlu ve ark. [6] çalışmasında NBA hastalarındaki en sık üç enfeksiyöz nedenden biri infektif endokardit olarak bulunmuştur. Bizim çalışmamızda ise NBA grubunda en sık saptanan enfeksiyon endokardit idi. Kollajen vasküler hastalıklar çeşitli serilerde genellikle ikinci, bazen de üçüncü sırada görülmekte olup bu olgularda Sistemik lupus eritematozus, poliarteritis nodosa, temporal arterit, erişkin Still hastalığı ilk sıralarda yer almaktadır [11, 16, 17]. Kollajen vasküler hastalıklar içinde yer alan ve tanısı klinik bulgularla konulan erişkin Still hastalığının NBA nedeni olarak giderek arttığı bildirilmektedir [18-20]. NBA hastalarında tanı konulamayan grup yurt içi serilerde \%4-17, yurt dışı serilerde \%5-25 oranında bildirilmiştir [7, 20-29]. Bu çalışmada NBA hastaları arasında tanı konulamayan hastaların oranı $\% 10,5$ olarak bulunmuştur.

Sonuç olarak bu çalışmada, enfeksiyon hastalıkları kliniğine ateş nedeniyle kabul edilen hastaların büyük bir kısmında ateşin enfeksiyon orjinli olduğu, NBA grubunun ise küçük bir oranı oluşturduğu görülmektedir. Ateşe neden olan enfeksiyonlar arasında pnömoni ve üriner enfeksiyonların halen önemini koruduğu ve ateşli hasta grubunda etiyoloji belli olmadan antibiyotik kullanımının çok yaygın olduğu anlaşılmaktadır. Diğer taraftan, enfeksiyon orjinli ateşin ayırıcı tanısında lökosit sayısı, C-reaktif protein gibi tetkiklerin her zaman yol gösterici olmayabileceği düşünülmektedir.

Çıkar ilişkisi: Yazarlar çıkar ilişkisi olmadığını beyan eder.

\section{Kaynaklar}

1. Köse Ş, Akkoçlu G, Türken M, Gozaydın A, Cavdar G, Ersan G. Ateş yüksekliği nedeniyle başvuran 88 olguda ateş etyolojisinin araştırılması. Klimik Derg https://doi. org/2010;23:18-21.10.5152/kd.2010.06

2. Rayhan $\mathrm{HH}$, Roberts NJ. Fever and fever of unknown etiology. In: Betts RF, Penn RL, Stanley W, eds. Reese and Betts' a Practical Approach to Infectious Diseases. 5th ed. Philadelphia: Lippincott Williams \& Wilkins, 2002;1-19

3. Tabak F. Ateş Patogenezi, ateş tipleri, erişkinde ateş yönetimi. In: Öztürk R, Mert A,ed. Ateşli Hastaya Yaklaşım Sempozyumu. İstanbul: iÜ Cerrahpaşa Tıp Fakültesi Sürekli Tıp Eğitimi Etkinlikleri Dizisi 2006;53:27-36.

4. Öncü $S$, Ertuğrul MB, Özsüt $H$, Eraksoy $H$, Çalangu S. Nedeni bilinmeyen ateş: 66 olgunun analizi. Klimik Derg 2003;16:108-112.

5. Mert A, Tabak F, Dumankar A, Aykaç İ, Süve İ, Aktuğlu Y. Nedeni bilinmeyen ateş: 50 olgu bildirisi, Klimik Derg 1996;9:18-21.

6. Zorlu S, Akalın H, Yılmaz E, Heper Y, Mıstık R, Helvaci S. Nedeni bilinmeyen ateş: 2007-2008 yıllarında kliniğimizde izlediğimiz 38 olgunun retrospektif analizi. Flora 2009;14:159-164. 
7. Karan MA, Erten N, Araz M, Taşçıŏlu C, Kaysı A. Nedeni bilinmeyen ateş: 26 vaka bildirisi. Klimik Derg 1995;8:124-126.

8. Demir N. Gram negatif bakterilerde genişlemiş spektrumlu beta-laktamaz (GSBL) üretimine katkıda bulunan çeşitli risk faktörlerinin araştırılması. Uzmanlık Tezi. T.C. Sağlık Bakanlığı, Dr. Lütfi Kırdar Kartal Eğitim Ve Araştırma Hastanesi İnfeksiyon Hastalıkları Ve Klinik Mikrobiyoloji Kliniği, İstanbul, 2006.

9. Çağatay AA, Karadeniz A, Özsüt $H$, Eraksoy $H$, Çalangu S. Nedeni bilinmeyen ateş: 150 olgu. Poster Bildiri. XII. Türk Klinik Mikrobiyoloji ve İnfeksiyon Hastalıkları Kongresi; 2005 Antalya; Türkiye.

10. Nayman Alpat $S$, Ünlü F, Erben N, Doyuk Kartal E, ÖZGÜNEŞ İ, Usluer G. Eskişehir'de nedeni bilinmeyen ateş etyolojisi. Flora 2009;14:67-71.

11. Mert A. Nedeni bilinmeyen ateşli hastaya klinik yaklaşım. In: Öztürk R, Mert A,ed. Ateşli Hastaya Yaklaşım Sempozyumu.İstanbul: iÜ Cerrahpaşa Tıp Fakültesi Sürekli Tıp Eğitimi Etkinlikleri Dizisi 2006;53:95-106

12. Saçar S, Hırçın Cenger D, Asan A, Toprak Kavas S, Demir M, Turgut H. Geriatrik infeksiyonların 50 olguda değerlendirilmesi. Pam Tıp Derg 2008;2:84-86 .

13. Goto M, Koyama H, Takahashi O, Fukui T. A Retrospective review of 226 hospitalized patients with fever. Intern Med 2007;46:17-22. https://doi. org/10.2169/internalmedicine.46.6038

14. Erten N, Saka B, Ozturk G,Karan MA, Tascioglu C, Dilmener M, Kaysi A. Fever of unknown origin: A report of 57 cases. Int J Clin Pract 2005;59:958-960.

15. Küçükardalı Y, Koçak N, Yazııı H, Çankır Z, Nalbant S, Top C, Danacı M. Nedeni bilinmeyen ateş: 82 olgu bildirisi. Flora 2001;6:171-177.

16. Hu Y, Lu H, Zhang $Y$, Jiang $W$, Yin $Y$, Pan $X$, Weng $X$. Fever of unknown origin: Revisit of 142 cases in a tertiary Chinese hospital. Biosci Trends 2008;2:44-46.

17. Willke A, Ergönül Ö. Nedeni bilinmeyen ateş: 25 olgunun incelenmesi. VII. Türk Klinik Mikrobiyoloji ve İfeksiyon Hastalıkları Kongresi; 11/15 Eylül 1994, Ürgüp; Türkiye.

18. Likuni $\mathrm{Y}$, Okada J, Kondo $\mathrm{H}$, Kashiwazaki S. Current fever of unknown origin 1982-1992. Intern Med 1994;33:67-73. https://doi.org/10.2169/ internalmedicine.33.67

19. Kazanjian PH. Fever of unknown origin: Review of 86 patients tereated in community hospitals. Clin Infect Dis 1992;15:968-973. https://doi.org/10.1093/ clind/15.6.968

20. Tabak F. Nedeni bilinmeyen ateş: 17 yıllık deneyim. Flora Derg 2001;6:260-266.

21. Petersdorf RG, Beeson PB. Fever of unexplanied origin: Report on 100 cases. Medicine 1961;40:1-30. https://doi.org/10.1097/00005792-196102000-00001
22. Larson EB, Featherstone HJ, Petersdrof RG. Fever of undetermined origin: Diagnosis and follow-up of 105 causes, 1970-1980. Medicine 1982;61:269-292. https://doi.org/10.1097/00005792-196102000-00001

23. Knockaert DC, Vanneste LJ, Vanneste SB, Bobbaers HJ. Fever of unknown origin in the 1980s. Arch Intern Med 1992;152:51-55. https://doi.org/10.1001/ archinte.1992.00400130077008

24. Çalangu S, Kayısı A, Dilmener M, Oran M, Ergun S. Nedeni bilinmeyen ateş (70 vakanın değerlendirilmesi). Tıp Fak Mecm 1984;47:480-489.

25. Çalangu S, Dilmener M, Eraksoy $\mathrm{H}$, et al. Fever of unknown origin (Report of 40 cases)(abstrac). Paper presented at: 4 th European Congress of Clinical Microbiology; 17-20 April 1989 Nice; France.

26. Aktaş F, Gürdoğan K, Şenol E, Hızel K, Ulutan F. Nedeni belli olmayan ateş: 34 olgunun değerlendirilmesi. Poster Bildiri. VIII. Türk Klinik Mikrobiyoloji ve İnfeksiyon Hastalıkları Kongresi; 6-10 Ekim 1997 Antalya; Türkiye.

27. Deal WB. Fever of unknown origin. Postgrad Med 1971;50:182-188. https://doi.org/10.1080/00325481.1 971.11697674

28. Howard P, Hahn HH, Palmer PI, Hardin WJ. Fever of unknown origin: A prospective study of 100 patients. Tex Med 1977;73:56-59.

29. Eyckmans L, Wouters R, Vandenbroucke J. Unexplained fever: Seven year experience. Acta Clin Belg 1973;28:232-237.

Etik onayı: Ankara Numune Hastanesi Etik Kurulu tarafından 2013 yılında onayı alınmıştır.

Dip not:* 5. EKMUD Bilimsel Platformu, 1-4 Nisan 2015, Çeşme'des özlüsunum olarak sunulmuştur.

* KLIMIK (Klinik Mikrobiyoloji ve İnfeksiyon Hastalıkları Derneği) 30. Yıl Kurultayı, 0912 Mart 2016 Antalya'da poster sunum olarak sunulmuştur.

*7. EACID( Eurasia Congress Of İnfectious Diseases), 30 September-3 October 2015, Tiblisi, Georgia'da poster sunum olarak sunulmuştur.

XX. TÜRK KLINIK MIKROBIYOLOJI VE INFEKSIYON HASTALIKLARI KONGRESI (KLiMiK Uluslararası Kongresi) , 13 -16 MART 2019, Antalya'da poster sunum olarak sunulmuştur. 